\title{
CORRELATION BETWEEN SOME BIO-AGENTS AND PLANTING DENSITIES ON DAMPING OFF CONTROL AND SOME HORTICULTURAL CHARACTERISTICS IN SWEET PEPPER UNDER GREENHOUSE CONDITIONS
}

\author{
Fahima H. Ayoub(1) and Ayat M. Ali(2) \\ (1) Vegetables Res. Dept., Horticulture Res. Inst., Agric. Res. Center, Giza, Egypt. \\ (2) Central Lab of Organic Agriculture, Agric. Res. Center, Giza, Egypt
}

Received: Oct. 18,2017

Accepted: Nov. 4, 2017

\begin{abstract}
This trail was carried out at Kaha Vegetable Research Station, Kalubia Egypt, during the two successive seasons of 2016 \& 2017. The objective of this study was to evaluate the effect of using different bio-agents at two planting densities on damping off disease incidence of sweet pepper. Some horticultural characteristics and yield were also studied. Two planting densities i.e. planting in low density $\left(2 \mathrm{plants} / \mathrm{m}^{2}\right)$ or high density $\left(3 \mathrm{plants} / \mathrm{m}^{2}\right)$ were used. Six different bio-agents were used (Trichoderma viride, Bacillus subtilis and Streptomyces $s p$. and their mixtures, $T$. viride with B. subtilis, $T$. viride with Strptomyces $s p$. and B. subtilis with Strptomyces sp.). Data revealed that, low density led to decrease disease incidence and improve chlorophyll content, compared with high density. Data also show an increase in some horticultural characteristics i. e. plant height, number of leaves and branches, leaf area, fresh and dry weights per plant when low planting density was used compared with high density. Fruit quality, i.e. fruit weight, length, diameter, flesh thickness and chemical characteristics were also increased with low density. Early yield, number of fruits per plant and total yield were also increased with low density. When bio- control treatments were applied, the obtained data revealed that mixture of $T$. viride with $B$. subtilis gave the best results and the reduction percentage in disease incidence were 69.4and 66.5\% during 2016 and 2017 seasons, respectively. Mixture of $B$. subtilis with Streptomyces $s p$. occupied the second rank and only 63.3 and $52.7 \%$ reduction were recorded compare with control. When growth characteristics, fruit quality and yield were considered, the obtained data showed that the highest yield and growth characteristics were noticed when mixture of $T$. viride and B. subtilis was used. Integration of these two factors (planting in low plant density with mixture of bio-agents) lead to improve the efficacy of the treatment and control of the disease.
\end{abstract}

Key words: Sweet pepper - plant density - damping off - Bio-control agents.

\section{INTRODUCTION}

Sweet Pepper (Capsicum annum L.) which belongs to Solananceae, is one of the most popular greenhouse crops in Egypt for local consumption as well as exportation, not only because of its economic importance, but also for the nutritional value of its fruits, it is an excellent source of natural colors and antioxidant compounds important for human health (Howard et al., 2000).

All species of pepper are susceptible to one or more soil borne fungi. These fungi causing damping-off of seedlings and root or crown rot of established plants. This type of disease is potentially the most serious to the grower, because it is difficult to recognize the problem, determine the causal factor, and control the pathogens. Damping-off is most often associated with the fungus Rhizoctonia solani and Pythium spp. Other fungi that occasionally cause damping- off include Sclerotinia sclerotiorum, Macrophomina phaseolina and Fusarium spp. and others (Rani and Sudini, 2013). Soil borne diseases are difficult to control because they are caused by pathogens 
which can survive for long periods in the absence of the normal crop host and often have a wide host range. Chemical control is very expensive and it is difficult to develop resistant varieties of plants to the soil borne pathogens Haggag et al. (2012).

Studies on plant density for different types of pepper have shown that plant density and plant arrangement can influence plant development, growth and the marketable yield of peppers (KhasmakhiSabet et al., 2009, Aminifard et al., 2010 and Islam et al., 2011. Plant density is an important determinant of yield. Yield per unit area tends to increase as plant density increase up to a point and then declines (Akintoye et al., 2009). Nasto et al. (2009) reported that increasing plant density resulted in greater yield ha-1 of bell pepper.

Disease management options include crop rotation, improving soil fertility levels, use of resistant cultivars, use of fungicides and biological control should be applied (Steyaert et al., 2003).

Bacillus is the most abundant genus in the rhizosphere, and the PGPR activity of some of these strains has been known for many years. There are a number of metabolites that are released by these strains, which strongly increase nutrient availability to the plants (Barriuso and Solano, 2008). It's able to produce IAA and thus helps in the plant growth promotion (Chakraborty et al., 2006).

Actinomycetes are one of the major components of the microbial populations present in the soil. Previous study showed that actinomycetes isolated from soil have the potential to inhibit the growth of several tested plant pathogens (Jeffrey et al., 2007).

Trichoderma spp. are ubiquitous fungi, frequently isolated from plant root ecosystems and commonly used in biological control of plant diseases. The fungal genus Trichoderma includes species of economic importance for production of antibiotics and enzymes (AbdEl Moity, 1981 and Howell, 2003) and induction of systemic acquired resistance in plants (Hanson and Howell, 2004). Some species of Trichoderma have displayed physical interaction (root surface colonization) with the plant, resulting in beneficial effects in plant metabolism such as enhancing growth, nutrient availability, improvement of crop production and enhancement of disease resistance (Yedidia et al., 2000; Martinez et al., 2009).

This work aims to find out:

- Correlation between planting density and disease incidence.

Effects of single or mixture of bioagents on damping off disease incidence in pepper plants

Effect of integration of plant density and bio-agents on some horticulture characteristics, yield and some chemical component in treated plants.

\section{MATERIALS AND METHODS}

This work was carried out under greenhouse conditions at Kaha Research Station, Kalubia Governorate to study the effect of some bio-agents on controlling damping off disease in sweet pepper, at two planting densities. Effect of these bio-agents and planting density on some horticultural characteristic and production were also studied under greenhouse conditions. This work was conducted during two successive seasons of 2015/2016 and 2016/2017. Soil in this area belongs to clay type with $\mathrm{pH}$ 8.1and (EC 0.53- 0.55mmhos).

Pepper seedlings 40 days old with three true leaves, Gedion F1 hybrid were used. Seedlings were transplanted, on August 13, 19 for the first and the second seasons, respectively .

The experiment was designed in a split plot arrangement with three replicates. Each replicate included 14 treatments which were the combination of two planting densities as main plots. Seven applications (six bioagents, single and mixture bio-agents, and control treatment) were arranged within the sub- plots. 


\section{Soil analysis for root rot pathogens in used soil:}

Soil samples were collected from used greenhouse before planting to detect types and population of root rot pathogens according to the method described by (Johnson et al., 1960).

\section{Root-rot pathogens Identification:}

Isolated fungi were identified according to their microscopic characteristics using key developed by Sneh et al, (1992) for Rhizoctonia solani, Booth (1971) for Fusarium and Ellis (1976) for Macrophomena.

\section{Planting densities}

Greenhouse $(9 \times 60 \mathrm{~m})$ was divided into two parts, one part was divided to seven ridges and one row of plants on each ridge with population of two plants $/ \mathrm{m}^{2}$ (10 plants (plot) and the other divided part contains fife ridges and two rows of plants on each ridge with population of three plants $/ \mathrm{m}^{2}$ (15 plants / plot). Each plot was $5 \mathrm{~m}^{2}$ for the two agriculture methods

\section{Single and mixture bio-agents Isolation, purification and identification of the bio-agents:}

Three different bio-agents namely Trichoderma viride (T.V), Bacillus subtilis (B.s) and Streptomyces sp. (St) were used. Trichoderma viride and $B$. subtilis were previously isolated, purified, identified and used by Ali (2013). Streptomyces sp. was isolated from pepper plants and identified according to the morphological and physiological characteristic using methods mentioned in Bergey's Manual of Determinative Bacteriology 9 (Cross, 2009). Purified isolates were used as bio-agents in this work.

\section{Propagation of bioagent}

Trichoderma viride isolate was grown on liquid gliotoxin fermentation medium (GFM) developed by Brain and Hemming (1945) for 11 days under complete darkness condition at $25^{\circ} \mathrm{C}$ to stimulate toxin production (Abd El Moity, 1981). Bacillus. subtilis isolate was grown in liquid nutrient glucose medium (NGM) developed by Dowson, (1957) for 2 days at $25^{\circ} \mathrm{C}$. Streptomyces sp. isolate was grown in Starch nitrate medium, for 7 days at $28-30^{\circ} \mathrm{C}$. (Waksman 1959). All bio-agents were prepared as suspension at the concentration of $25 \times 10^{6} / \mathrm{ml}$. Different bioagents in addition to three different mixtures of bio-agents were tested to study the efficacy of the different single bio-agents on disease control. Each mixture was prepared by mixing the two antagonists at the rate 1:1. The three different mixtures, i.e. T. viride with $B$. subtilis, $T$. viride with Strptomyces sp. and B. subtilis with Strptomyces sp. were prepared. Pepper seedlings were dipped in different bioagents separately for 20 minutes prior to transplanting. Treated plants were transplanted in natural infested soil. Plots without any treated seedlings were used as control. All treatments were examined periodically and percentages of disease incidence were recorded in each treatment. Examination process was repeated till 45 days from transplanting time. The total percentages of disease incidence were calculated and percentage of reduction in disease incidence due to different treatments was calculated.

The previous applications were conducted to early morning. Drip irrigation and other culture methods such as basic fertilization and pesticides were applied as recommended by Ministry of Agriculture.

\section{Data recorded for the different characters are as follows:}

\section{1- Determine efficacy of different treatments:}

The total percentages of disease incidence were calculated, after 45 days from transplanting and percentages of reduction in disease incidence due to different treatments were calculated as follows: 
$\%$ Disease incidence = Number of dead plant

Total number of plants

II- Horticultural characteristics:

The following data were recorded:

1- Vegetative growth characters :

Samples of pepper plants were taken at the productive of fruiting stage from each sub-plot to estimate plant height $(\mathrm{cm})$, number of branches and leaves per plant. Leaf area $\left(\mathrm{cm}^{2}\right)$ for the upper six leaves of plant, using LI 3000 Portable Area Meter (PAM) No. 5, produced by Li-cor Pennsylvania, fresh and dry weights (g/plant) which determined for three plants pulled up randomly from each replicate and dried at $70^{\circ} \mathrm{C}$ for $72 \mathrm{~h}$.

\section{2-Early and total yield :}

Data were recorded on early and total yield as a number and weight of picked fruits. Early yield was recorded for picked fruits of the first four harvests, while total yield was recorded for all pickings during the harvesting period.

\section{3-Fruit quality :}

Data concerning fruit characters were collected when the market stage reached the marketing fruit size. Data were recorded on average fruit length $(\mathrm{cm})$, average fruit diameter $(\mathrm{cm})$, flesh thickness and average fruit weight $(\mathrm{g})$.

\section{4- Chemical contents of plant and fruits :}

Data were recorded on fruits from the third picking for ascorbic acid contents (mgl100g fresh weight) according to the method described by A.O.A.C. (2000)., chlorophyll content was determined at the flowering stage using Minolta Chlorophyll Meter SPAD- 501 as SPAD . Homogeneous suspensions were analyzed to find out if there is any reduction in total soluble solids (TSS). TSS in different treatments were determined by a hand refractometer and were expressed as percentage according to A.O.A.C. (2000).

\section{III- Statistical analysis :}

The obtained data were subjected to the analysis of variance procedure using the L.S.D. method at $5 \%$ level of significance according to Gomez and Gomez (1984).

\section{RESULTS AND DISCUSSION 1-Percentage of established pathogenic fungi in used soil}

Data presented in Table (1) revealed that three different pathogenic fungi were isolated. These fungi identified as Rhizoctonia solani, Fusarium solani and Macrophomina phaseolina. Results in Table (1) indicate that R.solani was the most frequently isolated fungus, followed by $M$. phaseolina, whereas $F$. solani was the least one.

In this work, different single and mixture bio-agents with planting densities were tested under Egyptian conditions to develop highly effective method can replace chemicals in controlling root rot diseases.

Table (1): Percentage of established pathogenic fungi in used soil

\begin{tabular}{|l|c|}
\hline \multicolumn{1}{|c|}{ pathogen } & percentage of occurrence of pathogen \\
& $\%$ \\
\hline R. solani & 25 \\
\hline M. phaseolina & 15 \\
\hline F. solani & 5 \\
\hline
\end{tabular}




\section{A: Effect of planting density:}

Disease incidence was reduced in low density and recorded 49.3 and $54.5 \%$ compared to the high density, 49.7 and $56 \%$ in the seasons of 2016 and 2017, respectively. This may be due to increase of root mass in infection court. This means contact between roots of different plants, consequently transfer the pathogen from diseased root of one plant to another of healthy plant. Increase of root mass in certain area also lead to increase root exudates which stimulate and attract more pathogens (Bailey et al. 1997). Positive correlation was noticed between reduction in disease incidence and increase in chlorophyll.

\section{B: Effect of bio-control agents:}

Many investigators reported the efficacy of bio-agents in plant protection against different soil borne pathogens. Some investigators explain this protection effect as antibiosis action occurred in court of infection (Matei and Matei, 2008). Data in Table (2) indicated that, $T$. viride stand as the most effective bio-agent compared with the other two bio- agents. Bacillus subtilis followed $T$. viride in this regard and reduced the disease by 46.9 and $46 \%$ with $T$. viride and 43.9 and $35.7 \%$ with B. subtilis in 2016 and 2017 seasons, respectively. Streptomyces sp. occupied the last rank and gave only 29.6 and $21.2 \%$ reduction in the two seasons. Data also indicate that using any couple of bio-agents as mixture led to synergistic effect in all cases with only one exception, mixture of $T$. viride and Streptomyces sp. These results are in harmony with those obtained by Saksirirat et al. (2009). Data also show that the most promising results were obtained when the mixture of $T$. viride and $B$. subtilis was used followed by the mixture of $B$. subtilis and Streptomyces sp.

\section{C: Effect of interaction}

In general, $T$. viride gave the best results in controlling damping off disease incidence in pepper plants both at 2016 and 2017 seasons, in the two planting densities compared with any other bio-agents used. Regarding the mixtures, $T$. viride and $B$. subtilis which recorded the highest reduction in the two seasons and the two planting densities. This mixture reduced the disease at the two planting densities and gave 68.6 and $70.2 \%$ reduction with the low plant density and 71.9 and $64 \%$ reduction with the high plant density in the two seasons. This is due to $T$. viride works as antagonist and mycoparasite (Monteiro et al., 2011) whereas $B$. subtilis produces a huge number of antibiotics and antifungal substances (Attia et al., 2011). This good system increase photosynthesis consequently amount of sugars and lead eventually to good yield. To proof this hypothesis chlorophyll content was determined in treated plants. Combination of these two factors (planting in low planting density with mixture of bio-agents) lead to improve the efficacy of the treatment. All treatments reduced disease incidence and improve chlorophyll content compare with control, significantly (Table 2).

\section{2- Vegetative growth characters: A: Effect of planting density:}

Obtained results indicated significant differences in all plant growth characteristics (Tables 3\&4). It is clear that, all growth characteristics i.e. plant height, number of branches and leaves per plant, leaf area as well as fresh and dry weights per plant were significantly increased in plants which planted in low density compared to those plants planted in high density during the two studied seasons. Plants grown in low density were sufficient to allow more light penetration which increases photosynthesis efficiency (Elattir (2002) and Aminifard et al., (2010). Moreover, the increments in growth of pepper plants as a result of planting in low density method also reduced the competition between plants for nutrients, water and light as reported by De-Viloria et al. (2002); Preece \& Read, (2005); Ara et al. (2007); (Abubaker, 2008) and Aminifard et al., (2010). 
Fahima H. Ayoub and Ayat M. Ali

Table (2): Effect of using single or mixture bio-agents in addition to two planting densities on disease incidence and chlorophyll content of pepper plants during two successive seasons.

\begin{tabular}{|c|c|c|c|c|c|c|}
\hline \multirow[b]{2}{*}{ Treatments } & \multicolumn{2}{|c|}{ Disease incidence \% } & \multicolumn{2}{|c|}{ \% Reduction } & \multicolumn{2}{|c|}{ Total chlorophyll (SPAD) } \\
\hline & 2016 & 2017 & 2016 & 2017 & 2016 & 2017 \\
\hline Low density(A) & 26.95 & 26.67 & 49.3 & 54.5 & 55.70 & 55.14 \\
\hline High density (B) & 28.62 & 29.90 & 49.7 & 56.0 & 51.30 & 51.50 \\
\hline L.S.D. 5\% & 0.69 & 0.51 & & & 0.50 & 0.80 \\
\hline St & 34.5 & 35.3 & 29.6 & 21.2 & 50.43 & 51.22 \\
\hline T.V & 26.0 & 24.2 & 46.9 & 46.0 & 55.50 & 51.98 \\
\hline B.s & 27.5 & 29.8 & 43.9 & 35.7 & 54.27 & 52.90 \\
\hline$S t+T . v$ & 24.5 & 26.8 & 50.0 & 40.2 & 54.40 & 52.52 \\
\hline$S t+B . S$ & 18.0 & 21.2 & 63.3 & 52.7 & 56.48 & 56.93 \\
\hline$T . v+B . S$ & 15.0 & 14.8 & 69.4 & 66.5 & 57.92 & 57.43 \\
\hline Control & 49.0 & 45.8 & 00.0 & 00.0 & 45.50 & 46.78 \\
\hline L.S.D. $5 \%$ & 0.96 & 1.72 & & & 1.33 & 1.02 \\
\hline$A \times S t$ & 34.0 & 32.3 & 28.7 & 30.4 & 51.20 & 51.80 \\
\hline$A \times T . V$ & 25.0 & 23.3 & 47.6 & 44.3 & 58.00 & 52.50 \\
\hline$A \times B . S$ & 27.0 & 28.3 & 43.4 & 46.3 & 56.20 & 53.10 \\
\hline$A x(S t+T . v)$ & 23.0 & 26.7 & 51.8 & 48.3 & 57.50 & 52.80 \\
\hline$A x(S t+B . s)$ & 17.0 & 20.0 & 64.4 & 62.2 & 60.00 & 60.60 \\
\hline$A x(T . v+B . S)$ & 15.0 & 12.3 & 68.6 & 70.2 & 61.00 & 61.20 \\
\hline Control $(A)$ & 47.7 & 43.7 & 00.0 & 00.0 & 46.00 & 47.00 \\
\hline $\mathrm{B} \times \mathrm{St}$ & 35.0 & 38.3 & 26.1 & 20.2 & 49.70 & 50.60 \\
\hline $\mathrm{B} \times T . V$ & 27.0 & 25.0 & 35.2 & 47.9 & 53.00 & 51.40 \\
\hline$B \times B . S$ & 28.0 & 31.3 & 46.7 & 34.8 & 52.30 & 52.70 \\
\hline $\mathrm{B} \times(S t+T . v)$ & 26.0 & 27.0 & 38.9 & 43.8 & 51.30 & 52.20 \\
\hline$B \times(S t+B . s)$ & 19.0 & 22.3 & 54.2 & 53.5 & 53.00 & 53.30 \\
\hline $\mathrm{B} \times(T . v x+B . S)$ & 15.0 & 17.3 & 71.9 & 64.0 & 54.80 & 53.70 \\
\hline Control (B) & 50.3 & 48.0 & 00.0 & 00.0 & 45.00 & 46.60 \\
\hline L.S.D. 5\% & 1.36 & 2.45 & & & 1.89 & 1.45 \\
\hline
\end{tabular}

St: Streptomyces sp T.v: Trichoderma viride B.s: Bacillus subtilis

\section{B: Effect of bio-agents:}

Data in Tables (3 and 4) indicated that there were significant differences between all treatments on vegetative growth characteristics during the two studied seasons. Data indicate that, all plants treated with bio-agents encouraged their vegetative growth compared to control. The vegetative growth expressed as plant height, number of leaves and branches per plant, leaf area, fresh and dry weight per plant. The best results were obtained from plants treated with mixture of $T$. Viride and $B$. Subtilis followed by mixture of Streptomyces sp. and $B$. subtilis. The lowest result was recorded by control treatment. The effect of bio-agents applications on plant growth is that Bacillus subtilis is able to produce IAA 
which helps in the plant growth promotion (Chakraborty et al., 2006). Trichoderma spp. also can improve plant growth and development (De Souza et al., 2008). Growth stimulation is evidenced by increases in biomass, productivity and increase nutrient absorption. Increase crop productivity associated with the presence of Trichoderma sp., has been observed in a broad range of species, such as cucumber, eggplant, pepper, tomato, lettuce and bean (Gravel et al., 2007).

Table (3): Effect of using single or mixture of bio-agents in addition to two planting densities on vegetative growth characteristics.

\begin{tabular}{|c|c|c|c|c|c|c|c|c|}
\hline \multirow[b]{2}{*}{ Treatment } & \multicolumn{2}{|c|}{ Plant height $(\mathrm{cm})$} & \multicolumn{2}{|c|}{ No. of leaves/plant } & \multicolumn{2}{|c|}{ No. of branches/plant } & \multicolumn{2}{|c|}{ Leaf area $\left(\mathrm{cm}^{2}\right)$} \\
\hline & 2016 & 2017 & 2016 & 2017 & 2016 & 2017 & 2016 & 2017 \\
\hline Low density(A) & 66.43 & 67.86 & 136.48 & 140.81 & 32.57 & 33.62 & 99.09 & 102.03 \\
\hline High density(B) & 62.90 & 63.80 & 117.43 & 121.95 & 28.19 & 29.10 & 95.19 & 96.30 \\
\hline L.S.D. $5 \%$ & 0.51 & 2.34 & 1.70 & 2.18 & 1.01 & 2.16 & 1.48 & 3.89 \\
\hline St & 60.83 & 61.50 & 116.67 & 124.17 & 26.17 & 27.67 & 89.57 & 91.20 \\
\hline T.V & 62.83 & 63.35 & 122.33 & 124.83 & 30.00 & 31.17 & 93.53 & 94.94 \\
\hline B.S & 68.50 & 69.65 & 129.33 & 136.17 & 32.83 & 33.33 & 100.52 & 100.63 \\
\hline$S t+T . v$ & 64.33 & 65.20 & 127.17 & 132.50 & 31.50 & 32.33 & 96.46 & 100.25 \\
\hline$S t+B . s$ & 70.67 & 71.33 & 136.83 & 140.17 & 33.33 & 34.00 & 102.27 & 102.99 \\
\hline$T . v+B . s$ & 73.50 & 75.78 & 154.83 & 158.83 & 36.83 & 37.50 & 113.79 & 115.78 \\
\hline Control & 52.00 & 54.00 & 101.50 & 103.00 & 22.00 & 23.50 & 83.83 & 88.24 \\
\hline L.S.D. $5 \%$ & 37 & 1.62 & 6.70 & 6.39 & 1.03 & 1.41 & 2.24 & 3.93 \\
\hline$A \times S t$ & 62.00 & 62.67 & 123.00 & 130.00 & 28.70 & 30.00 & 90.47 & 91.40 \\
\hline$A \times T . V$ & 64.70 & 66.00 & 129.70 & 130.30 & 31.00 & 32.30 & 96.33 & 98.32 \\
\hline$A \times B . S$ & 70.30 & 71.00 & 141.00 & 148.30 & 35.00 & 35.30 & 100.81 & 102.3 \\
\hline$A x(S t+T \cdot v)$ & 67.70 & 68.67 & 137.00 & 143.30 & 33.70 & 34.30 & 98.23 & 102.9 \\
\hline$A x(S t+B . s)$ & 73.30 & 74.00 & 145.00 & 150.00 & 35.70 & 36.30 & 102.82 & 104.27 \\
\hline$A x(T . v+B . s)$ & 74.30 & 77.33 & 177.00 & 179.70 & 40.70 & 41.30 & 120.02 & 122.76 \\
\hline Control (A) & 52.70 & 55.33 & 102.70 & 104.00 & 23.70 & 25.70 & 84.97 & 92.24 \\
\hline $\mathrm{B} \times \mathrm{St}$ & 59.70 & 60.33 & 110.30 & 118.30 & 23.70 & 25.30 & 88.66 & 90.99 \\
\hline $\mathrm{B} \times T . V$ & 61.00 & 60.67 & 115.00 & 119.30 & 29.00 & 30.00 & 90.73 & 91.57 \\
\hline$B \times B . S$ & 66.70 & 68.33 & 117.70 & 124.00 & 30.70 & 31.30 & 100.24 & 98.94 \\
\hline$B \times(S t+T \cdot v)$ & 61.00 & 61.67 & 117.30 & 121.70 & 29.30 & 30.30 & 94.69 & 97.58 \\
\hline$B \times(S t+B . s)$ & 68.00 & 68.67 & 128.70 & 130.30 & 31.00 & 31.70 & 101.73 & 101.72 \\
\hline $\mathrm{B} x(T . v+B . S)$ & 72.70 & 74.23 & 132.70 & 138.00 & 33.00 & 33.70 & 107.56 & 108.79 \\
\hline Control (B) & 51.30 & 52.67 & 100.30 & 102.00 & 20.70 & 21.30 & 82.69 & 84.50 \\
\hline L.S.D. 5\% & 1.90 & 2.30 & 9.60 & 9.03 & 1.45 & 1.99 & 3.17 & 5.56 \\
\hline
\end{tabular}

St: Streptomyces sp T.v: Trichoderma viride B.s: Bacillus subtilis 
Fahima H. Ayoub and Ayat M. Ali

Table (4): Effect of using single or mixture of bio-agents in addition to two planting densities on fresh and dry weight parameters.

\begin{tabular}{|c|c|c|c|c|c|c|c|c|}
\hline \multirow[t]{2}{*}{ Treatment } & \multicolumn{2}{|c|}{$\begin{array}{l}\text { Plant fresh weight } \\
\text { (g) }\end{array}$} & \multicolumn{2}{|c|}{$\begin{array}{l}\text { Root fresh weight } \\
\text { (g) }\end{array}$} & \multicolumn{2}{|c|}{$\begin{array}{l}\text { Plant dry weight } \\
\text { (g) }\end{array}$} & \multicolumn{2}{|c|}{$\begin{array}{l}\text { Root dry weight } \\
\text { (g) }\end{array}$} \\
\hline & 2016 & 2017 & 2016 & 2017 & 2016 & 2017 & 2016 & 2017 \\
\hline Low density(A) & 328.19 & 346.29 & 27.29 & 29.05 & 38.70 & 41.00 & 4.65 & 5.31 \\
\hline High density(B) & 268.71 & 280.52 & 23.81 & 25.38 & 33.31 & 35.10 & 4.06 & 4.55 \\
\hline L.S.D. $5 \%$ & 13.20 & 13.99 & 1.53 & 2.03 & 1.09 & 1.08 & 0.37 & 0.05 \\
\hline St & 261.17 & 273.17 & 22.83 & 25.33 & 31.58 & 32.75 & 3.37 & 3.77 \\
\hline T.V & 274.67 & 288.17 & 25.00 & 26.17 & 34.03 & 35.48 & 4.32 & 4.85 \\
\hline B.S & 311.67 & 325.50 & 27.00 & 28.83 & 38.17 & 41.87 & 4.78 & 5.50 \\
\hline$S t+T . v$ & 299.50 & 314.50 & 26.50 & 28.17 & 38.33 & 40.33 & 4.53 & 5.07 \\
\hline$S t+B . s$ & 336.00 & 354.17 & 27.83 & 29.33 & 42.67 & 45.00 & 4.97 & 5.92 \\
\hline T.v + B.S & 357.33 & 379.83 & 30.00 & 33.00 & 46.33 & 48.92 & 5.70 & 6.18 \\
\hline Control & 248.83 & 258.50 & 19.67 & 19.67 & 20.92 & 22.00 & 2.82 & 3.25 \\
\hline L.S.D. $5 \%$ & 12.09 & 8.50 & 1.48 & 1.45 & 1.86 & 1.29 & 0.26 & 0.27 \\
\hline$A \times S t$ & 272.30 & 288.00 & 24.30 & 27.70 & 34.67 & 36.00 & 3.50 & 3.87 \\
\hline A $\times T . V$ & 297.00 & 316.30 & 26.00 & 28.00 & 37.07 & 38.73 & 4.50 & 5.30 \\
\hline$A \times B . S$ & 351.00 & 362.70 & 28.30 & 29.70 & 41.33 & 44.23 & 5.23 & 6.00 \\
\hline$A x(S t+T \cdot v)$ & 338.00 & 354.30 & 27.70 & 29.00 & 39.33 & 42.00 & 5.00 & 5.53 \\
\hline$A x(S t+B . s)$ & 376.00 & 400.00 & 28.70 & 30.00 & 45.67 & 48.33 & 5.27 & 6.33 \\
\hline$A x(T . v+B . s)$ & 398.30 & 424.00 & 32.70 & 36.70 & 50.33 & 54.00 & 6.10 & 6.67 \\
\hline Control (A) & 264.70 & 278.70 & 23.30 & 22.30 & 22.50 & 23.67 & 2.97 & 3.50 \\
\hline $\mathrm{B} \times \mathrm{St}$ & 250.00 & 258.30 & 21.30 & 23.00 & 28.50 & 29.50 & 3.23 & 3.67 \\
\hline $\mathrm{B} \times T . V$ & 252.30 & 260.00 & 24.00 & 24.30 & 31.00 & 32.23 & 4.13 & 4.40 \\
\hline$B \times B . S$ & 272.30 & 288.30 & 25.70 & 28.00 & 35.00 & 39.50 & 4.33 & 5.00 \\
\hline$B \times(S t+T \cdot v)$ & 261.00 & 274.40 & 25.30 & 27.30 & 37.33 & 38.67 & 4.07 & 4.60 \\
\hline$B \times(S t+B . s)$ & 296.00 & 308.30 & 27.00 & 28.70 & 39.67 & 41.67 & 4.67 & 5.50 \\
\hline$B x(T . v+B . S)$ & 316.30 & 335.70 & 27.30 & 29.30 & 42.33 & 43.83 & 5.30 & 5.70 \\
\hline Control (B) & 233.00 & 328.30 & 16.00 & 17.00 & 19.33 & 20.33 & 2.67 & 3.00 \\
\hline L.S.D. 5\% & 17.10 & 12.02 & 2.1 & 2.1 & 2.64 & 1.82 & 0.40 & 0.38 \\
\hline
\end{tabular}

St: Streptomyces sp T.v: Trichoderma viride B.s: Bacillus subtilis 


\section{C: Effect of interaction:}

Regarding the interactions between the two planting densities and bio-agents application, data in Tables (3\& 4) showed significant effects on some growth characteristics in terms of plant height, number of leaves and branches per plant, leaf area, fresh and dry weights per plant in comparison with control. The most effective interaction treatments regarding the previous growth characteristics were planting in low density with using mixture of $T$. Viride and $B$. Subtilis followed by mixture of Streptomyces sp. and $B$. subtilis. Moreover, all the interaction treatments at low planting density with bio-agents gave significantly higher effect on the previous growth characteristics when compared with control. The increments in the growth of pepper plants as a result of planting in low density may be attributed to the reduction of humidity which encourage several plant diseases and cause physiological defects (Coakley et al. 1999). Bacillus spp. and Streptomyces spp. enhance plant growth through various forms, such as: (i) reducing ethylene production, allowing plants to develop longer roots and better establish during early stages of growth, due to the synthesis of aminocyclopropane1carboxylate (ACC) deaminase which modulates the level of ethylene by hydrolyzing ACC, a precursor of ethylene, in ammonia and a-ketobutyrate (Glick, et al, 1998); (ii) producing or changing the concentration of plant growth regulators like (IAA) (Ahmad et al., 2008); (iii)raising the solubilisation of nutrients with consequent increase in the supply of bioavailable phosphorous and other trace elements for plant uptake (Glick, 1995); (iv) production of phytohormones such as auxins, cytokinins and Gibberelins (Glick, 1995); and (v) synthesis of antibiotic and other pathogendepressing substances such as siderophores, cyanide and chelating agents that protect plants from diseases (Kamnev, \& Lelie 2000).

\section{3-Early and total yield \\ A: Effect of planting density:}

Results in Table (5) revealed that, low density of plants on the ridge resulted in high significant increase in early yield, number of fruits per plant and total yield during the two studied seasons compared to the high density. Increasing of total yield regarding to the planting density may be due to the increasing of number of branches and fruits per plant. This result is in conformity with the findings of Cavero et al. (2001), Ara et al. (2007), Nasto et al. (2009) and Aminifard et al. (2010). This arises due to the fact that the competition is less in the low planting density than at the high planting density. The competition might be high for nutrients, physical spaces and water (LawOgbomo and Egharevba, 2009).

\section{B: Effect of bio-agents application:}

Treatment with bio-agents, Table (5) showed that the previous treatments increased early yield, number of fruits per plant and total yield ( $\mathrm{kg} \mathrm{/} \mathrm{plant)} \mathrm{when}$ compared with control during the two studied seasons. These results may be due to the effect of bio-agents on reducing some diseases of pepper as shown in Table (2) and enhancing plant growth as shown in tables (3\&4). Similar results were found by Abdel-Kader, et al. (2012) and Alharbi et al. (2014).

\section{C: Effect of interaction:}

The interaction between the two planting density and root application with bio-agents are shown in Table (5), where data clear significant effects on early yield, number of fruits per plant and total yield as compared to control. The most effective interaction regarding the previous characteristics was observed by using low planting density with mixture of $T$. Viride and $B$. subtilis, compared to control. This result is in agreement with the findings of Nasto et al. (2009) who reported that increasing plant density resulted in greater yield ha-1 of bell pepper. Wider spacing on the other hand led to increase in the yield per plant with bigger fruits. 
Table (5): Effect of using single or mixture of bio-agents in addition to two planting densities on number and weight of early and total yield/plant

\begin{tabular}{|c|c|c|c|c|c|c|c|c|}
\hline \multirow{3}{*}{ Treatment } & \multicolumn{4}{|c|}{ Early yield/plant } & \multicolumn{4}{|c|}{ Total yield/plant } \\
\hline & \multicolumn{2}{|c|}{2016} & \multicolumn{2}{|c|}{2017} & \multicolumn{2}{|c|}{2016} & \multicolumn{2}{|c|}{2017} \\
\hline & No. & $\begin{array}{c}\text { weight } \\
(\mathrm{kg})\end{array}$ & No. & $\begin{array}{c}\text { weight } \\
(\mathrm{kg})\end{array}$ & No. & $\begin{array}{c}\text { weight } \\
(\mathrm{kg})\end{array}$ & No. & $\begin{array}{c}\text { weight } \\
(\mathrm{kg})\end{array}$ \\
\hline Low density(A) & 4.38 & 0.606 & 5.02 & 0.717 & 26.01 & 3.41 & 27.3 & 3.60 \\
\hline High density(B) & 3.64 & 0.453 & 4.13 & 0.539 & 23.03 & 2.79 & 23.9 & 3.02 \\
\hline L.S.D. 5\% & 0.32 & 0.05 & 0.24 & 0.01 & 0.6 & 0.1 & 0.8 & 0.29 \\
\hline St & 3.33 & 0.400 & 3.87 & 0.480 & 20.8 & 2.40 & 21.5 & 2.59 \\
\hline$T . V$ & 3.68 & 0.450 & 4.22 & 0.530 & 22.5 & 2.64 & 22.8 & 2.75 \\
\hline B.s & 4.50 & 0.610 & 5.08 & 0.680 & 25.3 & 3.38 & 26.2 & 3.44 \\
\hline$S t+T \cdot v$ & 4.27 & 0.550 & 4.8 & 0.620 & 24.6 & 3.10 & 24.6 & 3.13 \\
\hline$S t+B . S$ & 4.77 & 0.670 & 5.28 & 0.780 & 28.1 & 3.82 & 30.1 & 4.09 \\
\hline$T . v+B . s$ & 5.12 & 0.760 & 5.87 & 0.986 & 31.9 & 4.25 & 34.8 & 5.11 \\
\hline Control & 2.4 & 0.274 & 2.92 & 0.318 & 18.5 & 2.07 & 19.1 & 2.05 \\
\hline L.S.D. $5 \%$ & 0.37 & 0.03 & 0.21 & 0.05 & 0.8 & 0.12 & 0.5 & 0.22 \\
\hline$A x S t$ & 4.1 & 0.495 & 4.5 & 0.570 & 21.4 & 2.57 & 21.8 & 2.67 \\
\hline A $x T . V$ & 4.3 & 0.528 & 4.8 & 0.609 & 22.6 & 2.78 & 23.1 & 2.86 \\
\hline$A \times B . s$ & 4.7 & 0.672 & 5.5 & 0.752 & 26.4 & 3.74 & 27.8 & 3.74 \\
\hline$A x(S t+T \cdot v)$ & 4.4 & 0.589 & 5.1 & 0.666 & 25.4 & 3.30 & 25.1 & 3.23 \\
\hline$A x(S t+B . s)$ & 5.0 & 0.755 & 5.7 & 0.897 & 29.8 & 4.32 & 33.9 & 4.71 \\
\hline$A x(T . v+B . S)$ & 4.3 & 0.862 & 6.3 & 1.163 & 36.2 & 4.80 & 38.9 & 5.77 \\
\hline Control $(A)$ & 2.9 & 0.430 & 3.3 & 0.364 & 20.2 & 2.34 & 20.6 & 2.21 \\
\hline $\mathrm{B} \times \mathrm{St}$ & 2.6 & 0.305 & 3.2 & 0.398 & 20.1 & 2.24 & 21.3 & 2.53 \\
\hline $\mathrm{B} \times T . V$ & 3.1 & 0.363 & 3.7 & 0.452 & 22.4 & 2.51 & 22.5 & 2.64 \\
\hline$B \times B . S$ & 4.3 & 0.547 & 4.7 & 0.599 & 24.2 & 3.02 & 24.7 & 3.14 \\
\hline$B \times(S t+T . v)$ & 4.1 & 0.503 & 4.5 & 0.574 & 23.9 & 2.91 & 24.1 & 3.02 \\
\hline$B \times(S t+B . s)$ & 4.5 & 0.582 & 4.9 & 0.668 & 26.3 & 3.33 & 26.3 & 3.48 \\
\hline $\mathrm{B} x(T \cdot v+B . s)$ & 4.9 & 0.665 & 5.4 & 0.810 & 27.6 & 3.69 & 30.6 & 4.45 \\
\hline Control (B) & 1.9 & 0.207 & 2.5 & 0.271 & 16.9 & 1.80 & 17.6 & 1.88 \\
\hline L.S.D. $5 \%$ & 0.52 & 0.04 & 0.3 & 0.08 & 1.1 & 0.16 & 0.7 & 0.31 \\
\hline
\end{tabular}

St: Streptomyces sp T.v: Trichoderma viride B.s: Bacillus subtilis

\section{4- Fruit quality}

A: Effect of planting density:

Data in Table (6) indicated positive and significant effect of planting density on fruit quality, i.e. fruit weight, length and diameter but no significant differences were shown as the results of planting density on flesh thickness during the two studied seasons. The increase of fruit length, diameter and weight may be due to the increases in 
vegetative growth characteristics with low density. Similar findings of increase in average fruit weight with wider spacing were reported by Miyao (2002) and Jovicich et al. (2003). This is likely due to the competition associated with the higher plant populations resulting in the lower fruit weight.

Table (6): Effect of using single or mixture of bio-agents in addition to two planting densities on fruit characteristics

\begin{tabular}{|c|c|c|c|c|c|c|c|c|}
\hline \multirow[b]{2}{*}{ Treatments } & \multicolumn{2}{|c|}{ Fruit weight (g) } & \multicolumn{2}{|c|}{ Fruit length $(\mathrm{cm})$} & \multicolumn{2}{|c|}{ Fruit diameter(cm) } & \multicolumn{2}{|c|}{$\begin{array}{c}\text { Flesh } \\
\text { thickness }(\mathrm{cm})\end{array}$} \\
\hline & 2016 & 2017 & 2016 & 2017 & 2016 & 2017 & 2016 & 2017 \\
\hline Low density(A) & 134.78 & 137.48 & 12.53 & 12.61 & 6.74 & 6.74 & 0.43 & 0.44 \\
\hline High density (B) & 121.52 & 128.00 & 11.90 & 11.99 & 6.33 & 6.31 & 0.41 & 0.42 \\
\hline L.S.D. $5 \%$ & 8.82 & 5.80 & 0.42 & 0.41 & 0.37 & 0.16 & N.S & N.S \\
\hline St & 117.70 & 124.83 & 11.08 & 11.38 & 6.02 & 6.10 & 0.39 & 0.40 \\
\hline T.V & 120.33 & 125.50 & 11.58 & 11.80 & 6.27 & 6.27 & 0.42 & 0.42 \\
\hline B.s & 134.17 & 132.50 & 12.58 & 12.42 & 6.78 & 6.75 & 0.44 & 0.44 \\
\hline$S t+T . v$ & 127.67 & 129.00 & 11.80 & 11.92 & 6.65 & 6.56 & 0.43 & 0.43 \\
\hline$S t+B . s$ & 139.67 & 147.33 & 13.53 & 13.48 & 6.93 & 6.97 & 0.46 & 0.46 \\
\hline T.v + B.S & 144.50 & 166.67 & 13.90 & 14.02 & 7.30 & 7.35 & 0.48 & 0.50 \\
\hline Control & 113.17 & 108.83 & 11.00 & 11.08 & 5.80 & 5.68 & 0.33 & 0.36 \\
\hline L.S.D. $5 \%$ & 5.34 & 6.70 & 0.31 & 0.35 & 0.26 & 0.21 & 0.05 & 0.06 \\
\hline$A x S t$ & 121.30 & 126.70 & 11.20 & 11.40 & 6.20 & 6.20 & 0.40 & 0.40 \\
\hline$A \times T . V$ & 123.70 & 127.70 & 11.80 & 12.00 & 6.40 & 6.40 & 0.43 & 0.43 \\
\hline$A \times B . S$ & 142.00 & 136.70 & 13.00 & 13.20 & 7.10 & 7.10 & 0.44 & 0.45 \\
\hline$A x(S t+T \cdot v)$ & 132.70 & 131.30 & 12.10 & 12.30 & 7.10 & 6.90 & 0.43 & 0.43 \\
\hline$A x(S t+B \cdot s)$ & 151.00 & 158.30 & 13.80 & 13.80 & 7.20 & 7.10 & 0.47 & 0.47 \\
\hline$A x(T . v+B . s)$ & 155.30 & 183.30 & 14.10 & 14.20 & 7.40 & 7.50 & 0.50 & 0.53 \\
\hline Control $(A)$ & 117.30 & 109.30 & 11.70 & 11.30 & 5.80 & 6.00 & 0.33 & 0.37 \\
\hline $\mathrm{B} \times \mathrm{St}$ & 113.70 & 123.00 & 11.00 & 11.30 & 5.90 & 6.00 & 0.38 & 0.40 \\
\hline $\mathrm{B} \times T . V$ & 117.00 & 123.30 & 11.30 & 11.60 & 6.10 & 6.10 & 0.40 & 0.40 \\
\hline B $\times$ B.s & 126.30 & 128.30 & 12.20 & 11.70 & 6.40 & 6.40 & 0.43 & 0.43 \\
\hline $\mathrm{B} x(S t+T \cdot v)$ & 122.70 & 126.70 & 11.50 & 11.50 & 6.20 & 6.20 & 0.42 & 0.43 \\
\hline $\mathrm{B} x(S t+B . s)$ & 128.30 & 136.30 & 13.20 & 13.10 & 6.70 & 6.80 & 0.44 & 0.45 \\
\hline$B \times(T . v+B . S)$ & 133.70 & 150.00 & 13.70 & 13.90 & 7.20 & 7.20 & 0.47 & 0.47 \\
\hline Control (B) & 109.00 & 108.30 & 10.30 & 10.80 & 5.80 & 5.40 & 0.33 & 0.35 \\
\hline L.S.D. 5\% & 7.65 & 9.40 & 0.44 & 0.49 & 0.37 & 0.29 & N.S & N.S \\
\hline
\end{tabular}

St: Streptomyces sp T.v: Trichoderma viride B.s: Bacillus subtilis 


\section{B: Effect of bio- agents}

Concerning the root application of bioagents on fruit quality, data in Table (6) indicated that, using these bio-agents gave positive effect on fruit length, fruit diameter, fruit weight and flesh thickness compared with control during the two studied seasons. Data revealed that maximum values of the previous fruit quality aspects were found with application of mixture of $T$. Viride and $B$. subtilis followed by mixture of Streptomyces $s p$.and $B$. subtilis. The lowest vegetative growth was recorded with control compared with the other treatments. Fruit quality may be affected by the bacterial treatments indirectly because of the phytohormones produced by bacteria. More vegetative growth can provide more photosynthesis activity and more synthesis of soluble matter, such as sugars, which affect fruit quality characteristics (Halil et al., 2011).

\section{C: Effect of interaction:}

Concerning the interactions between planting density and bio-agent's application data in Table (6) showed significant effects on some fruit quality in terms of fruit weight, length and diameter, but no significant differences were shown between treatments on flesh thickness during the two studied seasons. The most effective interaction treatments regarding the previous fruit characteristics were obtained when pepper plants were grown in low planting density and treated with mixture of $T$. viride and $B$. subtilis.

\section{5-Chemical fruit composition A: Effect of planting density:}

Concerning the parameters of chemical composition of sweet pepper fruits, it is clear in Table (7) that, fruit samples collected from low planting density gave significant increase in total soluble solids (TSS) and vitamin $C$ in both seasons. This result is in conformity with the findings of Aminifard et al. (2010) in paprika pepper. These results may be due to the increasing of the root density and vegetative growth characteristics as shown in Tables (3\&4) which increased the water and nutrients uptake.

\section{B: Effect of bio-agents:}

Roots treated with bio-agents significantly increased chemical parameters of sweet pepper fruits as shown in Table (7) during the two studied seasons, these data indicated a positive effect of bio- agent's application on the fruit TSS and ascorbic acid contents. Data revealed that maximum values of the previous chemical contents were found with the application of mixture of $T$. viride and $B$. subtilis followed by mixture of Streptomyces $s p$. and B. subtilis for fruit TSS and ascorbic acid compared with control. This result is in conformity with the findings of Halil et al. (2011) in sour sherry.

\section{C: Effect of interaction:}

Regarding to the interactions between planting densities and bio- agents application, data in Table (7) indicate that, the most effective interaction treatments regarding the fruit ascorbic acid and TSS content were obtained from plants grown in low planting density using mixture of $T$. viride and $B$. subtilis or mixture of Streptomyces sp. and $B$. subtilis at the first and the second seasons. 
Table (7): Effect of using single or mixture of bio-agents in addition to two planting densities on chemical fruit characteristics

\begin{tabular}{|c|c|c|c|c|}
\hline \multirow[b]{2}{*}{ Treatment } & \multicolumn{2}{|c|}{ TSS $\%$} & \multicolumn{2}{|c|}{ V.C mg/100g f.w. } \\
\hline & 2016 & 2017 & 2016 & 2017 \\
\hline Low density(A) & 5.57 & 5.60 & 163.99 & 165.67 \\
\hline High density(B) & 5.29 & 5.30 & 124.88 & 145.89 \\
\hline L.S.D. $5 \%$ & 0.16 & 0.22 & 1.53 & 2.28 \\
\hline St & 5.08 & 5.17 & 144.62 & 145.28 \\
\hline$T . v$ & 5.33 & 5.42 & 152.17 & 152.91 \\
\hline B.s & 5.58 & 5.53 & 154.49 & 156.98 \\
\hline$S t+T . v$ & 5.58 & 5.43 & 154.16 & 155.04 \\
\hline$S t+B . S$ & 5.83 & 5.75 & 160.39 & 163.45 \\
\hline T.v + B.S & 5.92 & 5.92 & 173.17 & 176.03 \\
\hline Control & 4.67 & 4.92 & 139.37 & 140.78 \\
\hline L.S.D. $5 \%$ & 0.56 & 0.54 & 0.94 & 3.73 \\
\hline$A \times S t$ & 5.20 & 5.30 & 154.60 & 155.48 \\
\hline$A \times T . V$ & 5.30 & 5.50 & 165.65 & 166.29 \\
\hline$A \times B . S$ & 5.80 & 5.70 & 166.00 & 168.93 \\
\hline$A x(S t+T \cdot v)$ & 5.70 & 5.50 & 165.68 & 166.56 \\
\hline$A x(S t+B . s)$ & 6.00 & 6.00 & 170.90 & 171.92 \\
\hline$A x(T . v+B . s)$ & 6.20 & 6.20 & 179.70 & 183.52 \\
\hline Control (A) & 4.80 & 5.00 & 145.40 & 147.01 \\
\hline $\mathrm{B} \times \mathrm{St}$ & 5.00 & 5.00 & 134.60 & 135.08 \\
\hline $\mathrm{B} \times T . V$ & 5.30 & 5.30 & 138.70 & 139.52 \\
\hline$B \times B . S$ & 5.30 & 5.40 & 143.00 & 145.03 \\
\hline $\mathrm{B} x(S t+T \cdot v)$ & 5.50 & 5.40 & 142.60 & 143.52 \\
\hline $\mathrm{B} x(S t+B . s)$ & 5.70 & 5.50 & 149.80 & 154.97 \\
\hline $\mathrm{B} x(T . v+B . s)$ & 5.70 & 5.70 & 166.70 & 168.55 \\
\hline Control (B) & 4.50 & 4.80 & 133.30 & 134.55 \\
\hline L.S.D. $5 \%$ & 0.81 & 0.75 & 1.33 & 5.28 \\
\hline
\end{tabular}

St: Streptomyces sp T.v: Trichoderma viride $\quad$ B.s: Bacillus subtilis 


\section{CONCLUSION}

As a conclusion, low planting density with the application of different bio-agents gave good results to control of damping off disease in sweet pepper as well as yield production compared to the high planting density and control. Data also showed that the most promising results were obtained when the mixture of $T$. viride and $B$. subtilis was used with low planting density. It gave high reduction in disease incidence as well as increase in vegetative growth characteristics, fruit quality and yield compared with high density.

\section{REFERENCES}

Abd El Moity, T.H. (1981). Further studies on the biological control of white rot disease of onion. Ph. D. Thesis, Fac. Agric., Menoufia University, 135 pp.

Abd El-Moity, T. H. (1985). Effect of single and mixture of Trichoderma harzianum isolates on controlling three different soil borne pathogens. Egypt, J. Micrbiology, Special Issue., pp.111-120.

Abdel-Kader, M. M., N. S. El-Mougy, M. D. E. Aly, S. M. Lashin and F. AbdelKareem (2012). Greenhouse biological approach for controlling foliar diseases of some vegetables. Advances in Life Sci., 2(4): 98-103.

Abubaker, S. (2008). Effect of plant density on flowering date, yield and quality attribute of bush beans (Phaseolus vulgaris L.) under center pivot irrigation system. Am. J. Agric. Biol. Sci., 3: 666668.

Ahmad, F., I. Ahmad and M.S. Khan (2008). Screening of free living rhizospheric bacteria for their multiple plant growth promoting activities. Microbiol. Res. 163, $173-181$.

Akintoye, H.A.; A.A. Kintomo and A.A. Adekunle (2009). Yield and fruit quality of watermelon in response to plant population. Int. J. Vegetable Sci., 15: 369-380.

Ali, Ayat M. (2013). Control of fungal diseases in strawberries under organic agriculture conditions. Ph. D. Thesis, Fac. Agric, Cairo Univ., pp.112.

Alharbi, A. A. and M. M. Alawlaqi (2014). Impact of Some Bacillus spp. Inducer Resistant Chemicals and Cows skim milk on management of pepper powdery mildew disease in Saudi Arabia. Life Sci. J.,11(4s):22-28.

Aminifard, M.H., H.A. roiee, S. Karimpour and H. Nemati (2010). Growth and yield characteristics of paprika pepper (Capsicum annum L.) in response to plant density. Asian J. Plant Sci., 9: 276280.

A.O.A.C. (2000). Official Method of Analysis. AOAC., Gaithersburg, USA.

Ara, N., M. K. Bashar, S. Begum and S.S. Kakon (2007). Effect of spacing and stem pruning on the growth and yield of tomato. Int. J. Sustain. Crop Prod., 2: 3539.

Attia, M., N. M. Awad, A. S. Turky and H. A. Hamed (2011). Induction of defense responses in soybean plants against Macrophomina phaseolina by some strains of plant growth promoting rhizobacteria. J. of Applied Sci. Res., 1507-1517.

Bailey, K. L., G. P. Lafond and D. Domitruk (1997). Effects of row spacing, seeding rate and seed-placed phosphorus on root diseases of spring wheat and barley under zero tillage. Canadian J. Plant Sci. 78: 145-150.

Barriuso, J. and B.R. Solano (2008). Ecology, Genetic Diversity and Screening strategies of Plant Growth Promoting Rhizobacteria (PGPR). J. Plant Nutr.,3: 1-17.

Booth, C. (1971). The genus Fusarium. Commonwealth Mycological Institute, Kew, Surrey, England. 235pp.

Brain, P.W. and H. G. Hemming (1945). Gliotoxin a fungi static metabolic product of Trichoderma viride. Ann. Appl. Biolo., 32: 214-220.

Cavero, J., R.O. Gill and M. Gutierrez (2001). Plant density affects yield, yield 
components and colour of direct-seed paprika pepper. J. Hort. Sci., 361: 76-79.

Chakraborty, U., B. Chakraborty and M. Basnet (2006). Plant growth promotion and induction of resistance in Camellia sinensis by Bacillus megaterium. J. Basic Microbiol. 46 (3): 186 - 195.

Coakley, S. M., H. Scherm and S. Chakraborty (1999). Climate change and plant disease management. Annual Review of Phytopathol. 37: 399-426.

Cross, T. (2009). The Actinomycetes. In: Bergey's manual of determinative bacteriology. Ninth Edition. (Eds. William, and Hensy), Williams and Wilkins. p. 605- 703.

De Souza, J.T., B.A. Bailey, A.W.V. Pomella, E.F. Erbe, C.A. Murphy, H. Bae and H.P. Hebbar (2008). Colonization of cacao seedlings by Trichoderma stromaticum, a mycoparasite of the witches broom pathogen, and its influence on plant growth and resistance, Biol. Control, 46: 36-45

De-Viloria, Z.A., R. De- Arteaga and L.T.D. Torrealba (2002). Growing of pepper (Capsicum annum) in response to different levels of NPK and sowing density. J. Hort. Sci., 72: 1062-1066.

Difco Manual. (1985). Dehydrated culture media and reagents for microbiology. 10th Ed. Difco laboratories Deforit Michigan, 48232 USA, p. 487- 623.

Dowson, W.J. (1957). Plant Disease Due to Bacteria. Second Ed., Cambridge the University Press, London, pp 23.

Elattir, H. (2002). Plant density effects on processing tomato growing in Morocco. J. Acta Hort., 613: 197-200.

Ellis, M.B. (1976). More dematiaceous hyphomycetes. Commonwealth Mycological Institute, Kew, Surrey, England.

Glick, B.R. (1995). The enhancement of plant growth by free living bacteria. Can. J. Microbiol.41, 109114.

Glick, B.R., D.M. Penrose and J. Li. (1998). A model for the lowering of plant ethylene concentrations by plant growth promoting bacteria. Journal of Theoretical Biology 190, 63-68.

Gomez, K. A. and A. A. Gomez (1984). Statistical procedures for agricultural research. Joho Wiley and Sons Inc. New York. 680 pp.

Gravel, V., H. Antoun and H.J. Tweddell (2007). Growth stimulation and fruit yield improvement of greenhouse tomato plants by inoculation with Pseudomonas putida or Trichoderma atroviride: possible role of indole acetic acid (IAA) Soil Biol.Biochem.,39: 1968-1977.

Haggag, H.E. Karima and Nadia G. ElGamal (2012). In vitro study on Fusarium solani and Rhizoctonia solani Isolates Causing the Damping Off and Root Rot Diseases in Tomatoes. Nature and Science 2012; 10(11): 55-65.

Halil, K., K. Recep, D. Fatih, A. Rafet and S. Fikrettin (2011). Effects of plant growth promoting rhizobacteria on fruit set, pomological and chemical characteristics, color values, and vegetative growth of sour cherry (Prunuscerasus cv. Kütahya) Turk J Biol. $35,283-291$.

Hanson, L.E. and C.R. Howell (2004). Elicitors of plant defense responses from biocontrol strains of Trichoderma viride. Phytopathol., 94: 171-176.

Howard, L.R., S.T. Talcott, C.H. Brenes and B. Villalon (2000). Changes in phytochemical and antioxidant activity of selected pepper cultivars (Capsicums pecies) as influenced by maturity. J. Agric. Food Chem. 48: 1713-1720.

Howell, C.R. (2003). Mechanisms employed by Trichoderma species in the biological control of plant diseases: the history and evolution of current concepts Plant Diseases, 87: 4-10

Islam, M., S. Saha, H. Akand and Md. A. Rahim (2011). Effect of spacing on the growth and yield of sweet pepper (Capsicum annum L.). Journal of Central European Agriculture, 2011, 12(2), p.328-335.

Jeffrey, LS., A.M. Sahilar, R. Son and S. Tosiah (2007). Isolation and screening of 
actinomycetes from Malaysian soil for their enzymatic and antimicrobial activities. JTAFS., 35: 159-164.

Johons, L. F., R.A. Curl, J.H. Bon and H.A. Fribourg (1960). Method for studying soil microflora and plant disease relationship. Second printing, Burgess publishing company, p.1-17.

Jovicich, E., D.J. Cantliffe and P.J. Stofella (2003). Spanish pepper trellis system and high plant density can increase fruit yield, fruit quality and reduced labour in hydroponic, passive-ventilated greenhouse crop. Acta Hortic. (ISHS), 614: 255-262.

Kamnev, A.A. and D. Lelie (2000). Chemical and biological parameters as tools to evaluate and improve heavy metal phytoremediation. Bioscience Reports20, 239-258.

Khasmakhi-Sabet, A., S. Sedaghathoor, J. Mohammady and A. Olfati (2009). Effect of plant density on bell pepper yield and quality. Int. J. Vegetable Sci., 15: 264271

Law-Ogbomo, K. and E. Egharevba (2009). Effects of planting density and NPK fertilizer application on yield and yield components of tomato (Lecopersicum esculentum Mill) in forest Location. World J. Agric. Sci., 5: 152-158.

Matei, G. M. and S. Matei (2008). Research on isolation, characterization and testing the interaction between Trichoderma harzianum and Botrytis cinerea for biological control of gray mold in strawberry. Horticulture, 51, 653657.(CAB abstract)

Martinez, C., F. Blanc, E. Le Claire, O. Besnard, M. Nicole and J.C. Baccou (2009). Salicylic acid and ethylene pathways are differentially activated in melon cotyledons by active or heatdenatured cellulase from Trichoderma longibra chiatum .Hort.Sci., 44: 20252027.

Miyao, G. (2002). Influence of plant population on transplanted processing tomatoes in the lower Sacramento valley. J. Acta Hortic., 613: 107-109.

Monteiro, S. L., M. Grondona, I. Llobell and A. Monte (2011). In vitro antifungal activity of Trichoderma harzianum, $T$. longibrachiatum, $T$. asperellum and $T$. atroviride against Botrytis cinerea to strawberry. Bulletin OILB/SROP, 25(10):253-256.

Nasto, T.H., A. Balliu and N. Zeka (2009). The influence of planting density on growth characteristics and fruit yield of peppers (Capsicum annuum L.). J. Acta Hortic., 830: 609-912.

Rani, V. D. and H. Sudini (2013). Management of soil borne diseases in crop plants. Inter. J. of Plant, Animal and Environmental Sci., V. 3(4): 156- 164.

Preece, J.E. and P.E. Read (2005). The biology of horticulture $.2^{\text {nd }}$. Copyright by John Wiley and Sons. New York. United States, 528p

Saksirirat, W., P. Chareerak and W. Bunyatrachata (2009). Induced systemic resistance of biocontrol fungus, Trichoderma sp.. against bacterial and gray leaf spot in tomatoes. Asian J. of food and Agro- Industry, Special issue, 99-104.

Sneh, B., I. Burpee and A. Ogoshi (1992). Identification of Rhizoctonia species. APS. press. USA, 133pp.

Steyaert, J. M., H. J. Ridgway, Y. Elad and A. Stewart (2003). Genetic basis of mycoparasitism: a mechanism of biological control by species of Trichoderma. New Zealand J. of Crop and Horti. Sci. 31:281-291.

Waksman, S.A. (1959). The actinomycetes Vol. 1 nature, occurrence and activities. The Williams \& Wilkins Co., Baltimore, pp.327.

Yedidia, N., Y. Benhamou and I. Kapulnik (2000). Chet Induction and accumulation of PR proteins activity during early stages of root colonization by the mycoparasite Trichoderma harzianum strain T203. Plant Physiol. Biochem., 38: 863-873. 


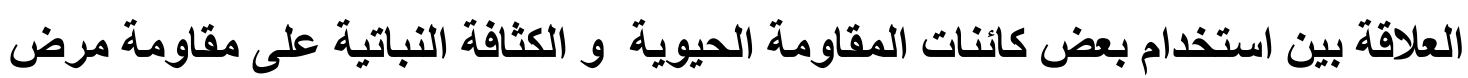

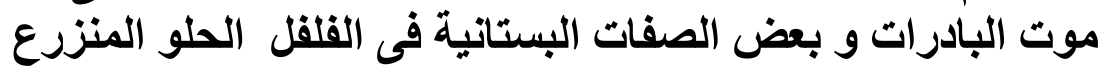 تحت ظروف الصوب}

\section{فهيمة هلال أيوب(1) ، آيات محمود علي(2) ـ الجيزة}

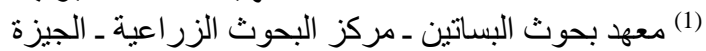

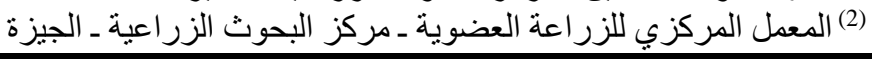

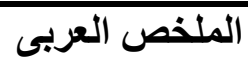

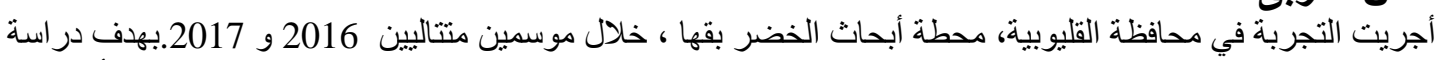

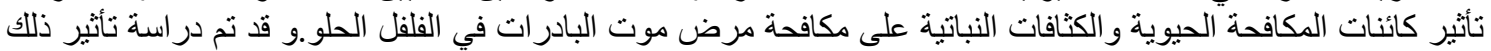

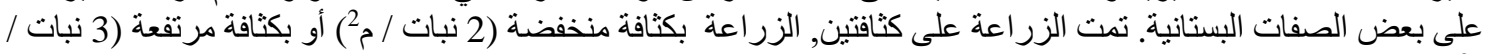

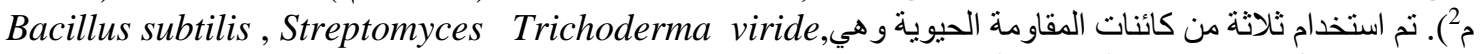
, (T. viride+ $\quad$ (T. viride + B. subtilis)

Streptomyces sp.), (Streptomyces sp. + B. subtilis)

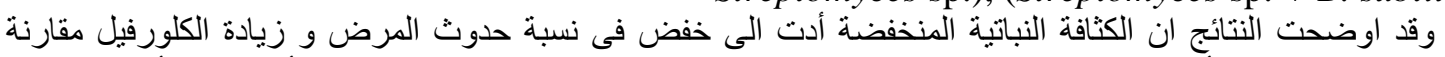

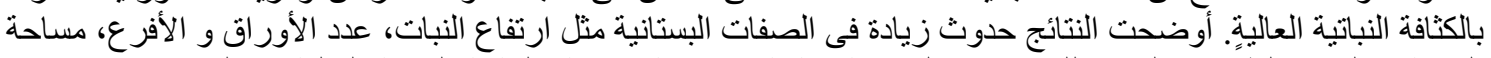

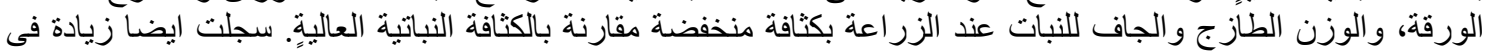

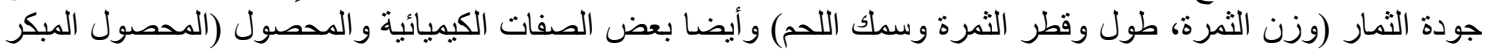

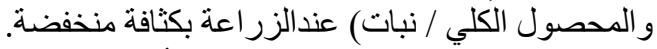

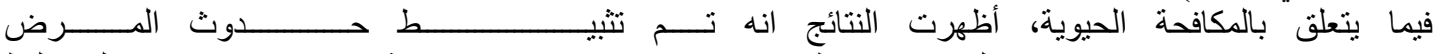

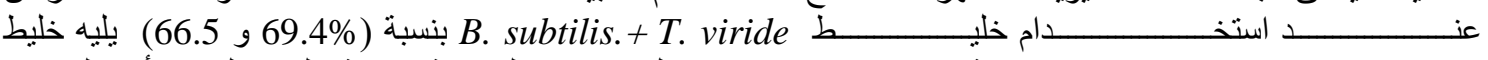
B. subtilis +Streptomyces sp.

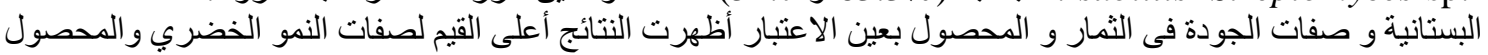

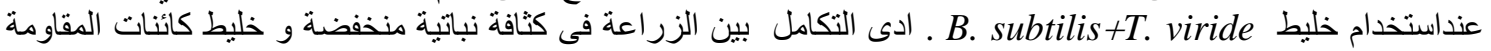

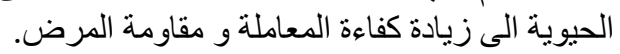

